\title{
1893 Yangını Sonrası Şam Emevi Camii Restorasyonu
}

\author{
The Restoration of the Ummayad Mosque in Damascus After the 1893 Fire
}

\section{Hilal KAZAN ${ }^{*}$}

Öz: I. Velid tarafindan 705-715 yılları arasında yapılan Şam Emevi/Ümeyye Camii tarih boyunca birçok kez yanmış, muhtelif doğal afet ve yıkımlar sonucu tamir edilerek yeniden ihya edilmiştir. Hilafeti devraldıktan sonra Osmanlı Devleti'nin İslam Dini'nin önemli ve mukaddes mabedlerine hizmeti, bu toprakları terk ettikleri devletin en çalkantılı ve ekonomik açıdan en zayıf olduğu XX. assın başlangıcına kadar devam etmiştir. Bu bağlamda Sultan II. Mahmud ve Sultan Abdülmecid'in Mescid-i Nebevi'yi büyük tamirattan geçirmeleri, Kanuni Sultan Süleyman başta olmak üzere diğer Osmanlı sultanları ile beraber II. Abdülhamid'in de aynı coğrafyada yaptığı tamirat ve imar hareketleri de hatırlanmalıdır. Şam Emevi Camii de bunlardan biridir. Camii, Müslüman-Türk hakimiyeti zamanında beş defa yandığından büyük onarımlar geçirmiştir. Bu onarımların sonuncusu ise Sultan II. Abdülhamid tarafından yapıldı. 15 Eylül 1893/5 Rebiulahir 1311 tarihinde geçirdiği büyük yangından hemen sonra vakit geçirilmeden harekete geçilip teftiş, keşif ve tamiratın icrasının sonuçlanması on yıl kadar devam eder. Bu bildiride yaşanan süreç sebep ve sonuçlarıyla beraber Osmanlı Arşivi belgeleri çerçevesinde ele alınacaktır.

Anahtar sözcükler: Şam Emevi Camii, Restorasyon, Mimarî, II. Abdülhamid, Yangın

Abstract: The Ummayad Mosque in Damascus was built between705-715 by the Caliph Al-Walid I. The mosque has been damaged by fire many times in its history and after various natural disasters and demolitions it has been rebuilt and repaired. After claiming the caliphate, the responsibility of the Ottoman State to the major Islamic sacred sites and places continued until the beginning of the XX century, when the state was in a turmoil and was economically weak. In this context, the restorations made to the Masjid Nabawi by Sultan Mahmud II and Sultan Abdulmecid, together with all the other Ottoman Sultans from Suleiman the Magnificent onwards, should be remembered without ignoring Abdulhamid II and his public works undertaken in this region including this restoration work. In the period of Islamic Ottoman rule this mosque had been damaged repeatedly by fire and great works of restoration were undertaken. The last of these restorations took place in the reign of Sultan Abdulhamid II. after a devastating fire in 1893, and major reconstruction work continued until 1897. This paper addresses this restoration work employing Ottoman archival documents.

Keywords: The Ummayad Mosque in Damascus, restoration, architecture, Abdulhamid II, fire

Hulefa-i Raşidin devrinden sonra kurulan Emevi Devleti (661-750), İslam topraklarının hızla genişlemesini sağlamış, buna bağlı olarak devlet ekonomik bakımdan da hayli zenginleşmiştir. $\mathrm{Bu}$ zenginlik bir taraftan devlet kurumlarının temellerini meydana getirirken diğer taraftan mevcut şehirlerde İslam kimliği oluşturma ve yeni İslam şehirlerinin imarını sağlamıştır. Bu bağlamda devlet merkezi Medine'den Şam'a taşınmıştır. Gerek dini, gerek sivil, gerekse askeri

\footnotetext{
*Yrd. Doç. Dr., İstanbul Üniversitesi, İlahiyat Fakültesi, İslam Sanatları Tarihi ABD, İstanbul. hllkzn@yahoo.com.
} 
mimari yapılarda İslam mimarisinin ve sanatının temelleri bu dönemde teşekkül etmiştir.

Şam Emevi Camii hiç şüphesiz ki Emeviler devrinde inşa edilen dini yapıların en önemlilerinden ve ihtişamlılarından biridir. MÖ I. yüzyıla ait bir Roma mabedi harabeleriyle yanında bulunan Theodosios dönemine (MS 379-395) ait Aziz Yohannes Kilisesi'nin tamamının I. Velid tarafından satın alınarak onun yerine MS 706-714 yılları arasında inşa edilmiştir. Ka'be-i Muazzama, Mescid-i Aksa ve Mescid-i Nebevi'den sonra inşa edilmiş olan İslam'ın en önemli ve büyük manevi değerleri haiz camiilerindendir. 37 x 137 metre ebadlarında, kıble duvarına paralel 3 nef ve onları mihrap hizasında kesen bir dikey nefli olarak inşa edilen camiinin mihrap üzerinde bir kubbesi ve dışında iki kat revaklı avlusu, dört mezhebe ait dört adet mihrabı, Arus, İsa ve Kayıtbay isimlerini taşıyan üç adet minaresi ile Bâbu Berîd, Bâbu Ceyrun, Bâbu'l-Feradis ve Bâbu'z-Ziyade adlı dört ana kapısı bulunmaktadır. Ayrıca içerisinde Hz. Yahya Türbesi, Hz. Hüseyin'in Kerbela'da kesilen başının teşhir edildiği yere yapılan bir makam gibi mukaddes küçük yapıları da barındırmaktadır (Yazıcı 108-109).

Osmanlıların Şam, dolayısıyla Emevî Câmii ile olan ilişkisi Sultan Yavuz Selim (15121520) devrinde başlamıştır. 1516 senesinde Mısır seferi esnasında sultan Şam'da bulunduğu süre içerisinde hem Moğol istilasından büyük yıkıma uğrayıp harabeye dönen şehri yeniden kalkındırmak için bir takım girişimlerde bulunmuş, hem de camii ziyaret etmiş ve onun için bir vakıf kurmuştur. Yayınlanan vakfiyeye göre, gerek Şam içinde gerek dışında yüzlerce dükkan, değirmen, arazi, meyve bahçeleri ve su kaynakları gibi çeşitli gelir getiren yerler camiinin ihtiyaçlarını karşılamak üzere vakfedilmiştir (Ateş 1978).

Bina tarih boyunca savaşlar ve diğer yandan deprem, yangın gibi tabii afetler nedeniyle yıkılmış, yanmış, tahrip edilmiş, ilaveler yapılmış bunların neticesinde muhtelif tarih ve evsafta tamirat görmüştür. Bu makalede ise camiinin 1893 senesinde geçirdiği büyük yangın ve sonrasında Sultan II. Abdülhamid devrindeki tamiratı Osmanlı Arşivlerindeki belgeler 1şı̆̆ında kronolojik olarak ele alınacaktır.

15 Eylül 1893 (5 Rebiulahir 1311) Pazar günü alaturka saate göre beş sularında camiide yangın çıkmış, hem itfaiye hem de askeriye anında müdahale etmesine rağmen hem içten hem dıştan çatıya çıkmak yükseklik sebebiyle zor olduğundan; çatının ve sakıfların da ahşap olması sebebiyle yangın süratle ilerlemiştir. Hz. Yahya (AS) makamının tamamı dahil olmak üzere cami-i şerif yanmış. Ayrıca camii çevresinde bulunan çarşıdaki 80-100 kadar nalıncı ve yemenici/ayakkabıcı dükkanı ile 10 tane de ev kısmen yanıp harap olmuştur. Ertesi gün 5. Ordu-y1 Hümayun kumandanlığının izni ile Sultan'a telgraf gönderilerek haberdar edilmiş. Konu hakkında derin bir inceleme başlatılmış; bununla beraber Evkaf-1 Hümayun Nezareti tarafından tamir termim işlerinin hemen başlatılması için padişahtan emir beklenmiştir (BOA, İ.HUS. 17/13). Ancak aynı yılın kasım ayına tarihli bir başka Fransızca belgede ise yanan dükkanların sayıs1 167, evlerin ise 24 olarak verilmektedir. Ayrıca bu durumdan 200000 kadar kişinin etkilenerek muzdarip olduğu yazılıdır (BOA, HR.SYS. 26/69). Yangın haberinin İstanbul'a ulaşmasının ardından halkta her hangi bir infiale sebep vermemek için olsa gerek 16 Eylül 1893 (5/R/1311)'de Sultan'ın müsteşarı tarafından yabancı gazeteciler müdürlügüne bir ferman gönderilerek “... tebliğ buyurulan emr-i ferman-i Hümayun-i Cenab-i Hilafet-penahi mantuk-i celilesine göre Şam'da muhterik olan Cami-i Şerif hakkında gazetelere harf-i vahid yazdırılmamast ..." istenmektedir (BOA, DH.MKT. 150/25).

Bu süreçte dikkat çeken yangının durumunun İstanbul'a günbegün aktarılmış olmasıdır. Bir sonraki gün Suriye Jandarma Komutanı Şahin tarafindan Dersaadet'e gönderilen telgrafta “... Asar-ı Atika-i İslamiye'den olup İslamiyet'in medar-ı iftihar-l yeganesi olan meşhur Camii-i Şerif-i Emeviyye ateş alarak tedbirsizlikten naşi tavassu'la derununda medfun Nebiy-yi zi-şan 
Yahya AS. türbesi tamamen Hz. Hüseyin Efendimiz'in makamı kısmen muhterik olmakta bulunduğu umum ehâli-i İslamiyeyi derunden dă̆ladı̆̆, etraftaki nalıncı çarşısı kamilen, mahallesiyle başka cihetlere de sirayet edip devam etmektedir..." denilmektedir (BOA, Y.PRK.AZJ. 27/79). Hadisenin üzerinden bir ay geçtikten sonra 17 Ekim 1893 tarihinde "ŞamŞerif Cami-i Kebir-i Emeviyye'nin ne suretle muhterik olduğu" başlı̆̆ı altında hazırlanan yangın raporu Dersaadet'e gönderilir. Halil Kemal mühürlü rapora göre; yangının çıktığı günlerde camiinin çatı ve saçaklarının kıble yönü tamir edilmektedir. Güvenilir bir kişinin verdiği ifade çerçevesinde ise amelenin birinin kullandığı nargileden çıkan bir kıvılcım ateşi yangına sebep olmuştur. Şiddetli rüzgar her türlü müdaheleye rağmen ateşin bir anda yayılıp 45 dakika içerisinde her şeyin kül olmasına sebebiyet vermiştir. Camiinin direkleri kırılıp parçalanmış, duvarlar ateşin şiddetinden yıpranmış, ardından yağan yağmurla beraber ise caminin duvarları yarısına kadar yıkılmıştır. Raporda ayrıca 175 dükkan ve 26 hanenin de yanıp yıkılmış olduğu bildirilmektedir (BOA, Y.PRK.AZJ. 27/79-12). Öte yandan hasar tespiti ve tamir edilmesi gereken yerleri belirlemek için oluşturulan İnşaat dairesi başkanı Hüseyin Paşa, İzzet Paşa ve Mimar Mösyö Valori Vedranko'dan müteşekkil keşif heyeti de çalışmalarda bulunup raporlarını hazırlamaktadırlar (İ. EV. 9/28-002-007).

Camiinin restorasyonu için bölgede bulunan askeri birliklerden Bekâi Aziz kazası jandarma bölüğü gönüllü olarak 140 liraya baliğ olan birer maaş bedellerini bağışlamış (BOA, İ.HUS. 17/111); yerel halktan bazı tekkelerde dervişler de cami-i şerifin tamiratı için aralarında para toplamışlardır. Bu toplanan yardım paraları ile hazırlanan planlar, keşif defterleri ve hadiseyi belgeleyen fotoğraflar, bölgede güvenilirliği ile tanınan Sultan Süleyman'ın Şam'daki hankâhının postnişini Hz. Halid'in biraderzadesi Şeyh Esad Efendi'nin beraberinde Dersaadet'e gönderilmiştir (BOA, Y.PRK.UM. 29/14).

Belgelerden anlaşıldığına göre Şam'da hazırlanarak Dersaadet'e gönderilen, ancak muhtevası hakkında bilgi bulunmayan lâyiha, keşif defterleri, fotoğraflar ve sair evrak, Meclis-i Mahsusa-i Vükela tarafından incelenmiş, bir üst yazıyla keşif defterlerinin iki gün içinde ilgili mühendisler tarafindan tetkik edilmesi için Erkan-1 Harbiye Dairesine gönderilmiştir (BOA, BEO 348/26041-1). Ayn1 zamanda bu belge ve raporlar Müze-i Hümayun'a da gönderilip zamanın müze müdürü Halil Edhem Bey'den (1861-1938) de görüş istenmiştir. Müzeden 10 Şubat 1894'de şöyle bir rapor gelir:

"Müze-i Hümayun Müdüriyetinden Evkaf-ı Hümayun Nezaret-i Celilesi'ne gönderilmiş 29 Kanunisani 1309/10 Şubat 1894 tarihli tezkere suretidir. Şam-i şerifde kâin olup geçende muhterik olan Emeviye Camii'nin yeniden inşası için mahallince erkan-ı harbiye zabitanı marifetiyle tertip edilen projede cami-i şerifin tarz-ı atik mimarisi nazar$i$ itibara alınmayı taksimat-ı dahiliye ve hariciyesince tamamiyle tarz-ı cedid bir mimariye muvafik şekil ve suret tasvir ve tersim olunduğu ve bu tasavvur icabından olarak cami-i mezkurun cihet-i hariciyesini teşkil eden ve 6 sene evvel Şam'a seyahat-i acizanemde re'yü'l-ayn müşahede olunduğu muhtelifü'l-elvan mermerleri ile müzeyyen bulunan gayet vasi meydanın vasatıyla etraf-ı erbaasinda mezkur ve kazalik mermerden masnu' amudlarla ezkar-ı tarihiyyeden ma'dud olacak sair asar-ı mevcudanin ylkalmasina velhasil mezkur camiinin yangin tesirinden masun kalan mahallerinin cihat-ı muhterikasinin iktisab eylemis olmadi ̆̆ hale kalbleriyle ona göre inşaata mübaşeret olunmak üzre idiği Şamdan suret-i hususiyede alınan haberlerden ma'a't-teessüf müsteban olmuştur. Mezkur camiinin bir çok yönden haiz olduğu ehemmiyet ve 
muhteremiyet hakkında zat-ı kemalat-ı slfat-ı daderilerine karşı arz ve tafsilat bi-lüzum ve şu veçhile uğradiğ kaza-i ihtirak üzerine emr-i tecdidine masruf olacak himmetin gerek mimariyyen gerek san'aten şekl$i$ kadimine temessül edebilmesi ve bununla beraber harikden masun kalan kisimlarının ve ale'l-husus balada arz olunan amudlarla sair müştemilat-ı kadimesinin ala-halihim ibka ve imarları hususlarına da şamil olması vücubu emr-imeczum iken bu dakikaların mahallince ademi takdiriyle mezkur camii bina-yl cedidince şekl-i kadiminin taklidine riayet olunmakdan maada bu fikr-i sakimden camiinin ehemmiyet-i tarihiyye ve sanaiyyesini muhatır olacak olan aksam ve müsstemilat-ı bakiyesi de hissedar-i indiras edilmesi ne derecelerde te'sirat-l vicdaniyeyi müstelzem teşebbüsat- mahtiyyandan olduğu keşf ve tayine yine irfan-ı celil-i nezaret-penahileri kafil olacağına ve tarz-ı cedid ile vuku' bulacak inşaat için 70-80 000 lira kadar para sarfi tahmin edildiği cümle-i istihbarattan olup halbuki aksam ve müsstemilat-i bakiyesini muhafaza ve ibka ile beraber camiinin hey'et-i kadimesine mutabık surette ihtiyar-ı inşaatın daha az masraf vukuunu temin etmiş bulunduğuna binaen ber-vech-i hasbi arz ve ihbar-ı keyfiyetle tasavvurat ve teşebbüsat-i m...nin tashihine delalet gibi bir emr-i hayr muvaffakiyyet- $i$ aliyyeyi asifanelerini an-hamimi'l-kalb temenni eylerim ol babda (BOA,Y.PRK.EV.2/22-1)".

Bu rapor takdir görür Sermimar Ohannes Efendi'nin, 15000 kuruş harcırah ve beraberinde Müze Müdürü Hamdi Bey ile Şam'a gönderilmeleri için Meclis-i mahsusa-i vükelâdan 27 Şubat 1894 tarihinde karar çıkar (BOA, Y.A.HUS.291/13). Bu zatların hangi tarihte yola çıkıp Şam'a vardıkları kesin bilinmemekle beraber 7 Ekim 1894'de İstanbul'dan Darülacaze inşaatı komisyonu azasından Mirliva İzzet Paşa ve inşaat ve istihkam dairesi 1. Şube müdürü Rasim Bey de aynı maksatla Şam'a gönderilirler (BOA, BEO, 489/36629). Yazıda camiinin inşaatının kararlaştırılması için öncelikle mevcud temellerinin iyice temizlenip ortaya çıkarılması da istenmektedir. Mirliva İzzet Paşa ile Binbaşı Rasim Bey'in Şam'a gönderilmesi mahalli halk tarafından memnuniyetle karşılanmıştır. Şam'da bulunan kalfalar tarafından çevrede mimari özelliği ve estetik güzelliğe sahip binalar üzerinde bir takım araştırmalar yapılmış; bu çalışmalar hakkında Dersaadet'e bilgi verilmiştir. 31 Ekim 1894 tarihinde İzzet Paşa ile Binbaşı Rasim Bey'den yapılan çalışmalar ve önerileri ihtiva eden, fenne muvafik mükemmel surette resim ve planı tanzim ederek göndermeleri istenmiştir (BOA, İ.HUS.30/100).

Osmanlı Devleti, bir taraftan büyük yıkımlara sebep olan 10 Temmuz 1894 İstanbul depremi ile sarsılmış, depremin yaralarının sarılması için yoğun çaba sarfederken diğer yandan siyasi, diplomatik ve ekonomik açılardan zor bir dönemden geçmesine rağmen belgelerden anlaşıldığına göre Emevi Camii'nin restorasyonu için başlatılan süreç her hangi bir inkıtaya uğramaksızın biraz uzun sürse de devam etmiştir. Bu arada Şam'da toplanan yardımlar 16000 liraya ulaşmış bu sebeple emeği geçen 4 kişiye 4 . Rütbeden nişanlar verilmiştir (BOA, DH. MKT. 204/86).

Mirliva İzzet Paşa, Binbaşı Rasim Bey, Suriye Başmühendisi Dimitri Vasiliyaki, Beyrut Başmühendisi Beşare ve Demiryolları Mühendisi Osman Vehbi'den müteşekkil heyet tarafından hazırlanan 20 Aralık 1894 tarihli dosya, ikinci keşif defteri, tarifname, resim ve fotoğrafları ihtiva etmektedir. Öngörülen restorasyon teklifine göre camiinin o dönemde yeni yeni kullanılmaya başlanan betonarme teknikle yeniden inşası tavsiye edilmekte, daha önce mermer olan camiinin iç sütunlarının Şam çevresinde çıkan mezze taşından $35-40 \mathrm{~cm}$ çapında taraklı, 
tesviyeli ve birbirine kurşun kenetle raptedilmiş olarak iki parça halinde yapılması; sütun başlarının besimeli (?) denen sert beyaz cins bir taştan arap tarzı şeklinde olmasi; kemerli olan duvarlarda iki kemer arasının delikli Marsilya tuğlası ile örülmesi; ayrıca kemerli tarafı yonma taşından söveli olması, çatının üzerinin demir putreller ile kaplanıp aralarının tuğla ile örülmesinin uygun olmayacağı onun yerine tamamen betonarme direkler üzerine inşa edilmesi ve bu tarz çatının Osmanlıda ilk kez yapılacağı; mihrap ve kıble duvarı haricinde kalan mermer gerektiren yerlerde umumiyetle mahalli mezze taşı tercih edilmesi; bu bölgelerin sıvalarında da mermer tozunun harca karıştırılarak yapılması tavsiye edilmektedir. Büyük kubbenin layihada belirtildiği gibi bazı mahalleri yıkıktır. Bunun için kubbenin bağlı olduğu 4 adet büyük kargir ayakları mermer ve mermer sırtında yerli taşından mozayik tarzında yapılmış olan kaplamaların yangından etkilenerek kısmen düşmüş kalanlar da mevcuduna ilaveten İtalya mermeriyle yerli taştan yeniden tamir suretiyle ve mevcud duvarlara çimento ve kumlu harçla doldurulmuş mozaik tarzında mevcuduna benzer şekilde kaplama inşası, taştan ibaret olan döşemenin gerek kemer ve sütunların düşmesiyle gerek ateşin tesirinden kısmen harap olduğundan bunların temizlenip siyah ve mezze taşlarının birbirine uyumlu ve cilalı olmak üzere değiştirilerek yeniden döşenmesi, süslemelerin sağlam kalan yerlerinin temizlenmesi dökülmüş ve tahrip olmuş yerlerin ise özel bir harç ile renklendirilmesi, minberin Marmara mermerinden yeniden imal edilmesi, camiinin kalem işlerinin bir kalemkar tarafından suluboya ile yapılması, hüsnühatlarının da Sultan'ın serhattatı tarafından yazılması gibi öneriler yer almaktadır (BOA, İ. EV. 9/28-002-002-007).

Fig. 1. Yangın Sonrası Şam Emevi Camii’nin Hali (İ̈̈, Nadir Eserler Ktp)

Gönderilen bu evraklar Hilafet merkezinden görevlendirilen bazı ümera-yı askeriye ve mimarlardan müteşekkil olunan heyet-i mahsusa tarafından değerlendirilerek 24 Mart 1895 tarihinde bir rapor hazırlanmıştır. Buna göre: "Teklif edilen usûl-i cedîd-i mimariyeye uygun olarak sütunlar imali ile yanan kısmın cephesinde bir takım değişikliler Cami-i Şerifin hususi 
tarihi bir ehemmiyeti ve İslam'in büyük manevi eserlerinden olması hasebiyle şeklinin ve görünüşünün değiştirilmesi hiçbir suretle caiz değildir" denilerek reddedilmiş. Hâl-i kadimi her ne ise onun aynı olmak üzere tamiratı lazımdır. Yanmadan evvel çekilmiş fotoğraflardan görülen şekline uygun tamamen eski halinde inşası için bir kıta cephe resmi tanzim kılındığı gibi mezkur mermer sütunlar yerine mahallinde mevcut mezze taşından kürsüler üzerine yine aynı taştan imal olunması ve üç dört parçadan oluşturularak yapılması; camiinin eski çatısı ahşap olduğundan gelecekte tekrar bir yangına maruz kalmaması için eski şekline sadık kalınarak demirden yapılmasi; gereken masrafın 4008686 kuruş tahmin ve takdir edildiği beyan olunmuştur. Bu masrafin 2719300 kuruşunun mahalli eşraf tarafından karşılanıp geri kalan 1289 386 kuruşun iane olarak sair vilayetlerden de toplanacak paralarla karşılanması planlanmış ve bu şekilde tamirata başlanmıştır (BOA, BEO.591/44256).

İnşaat başladıktan kısa süre sonra mimar tayini gündeme gelmiştir. Mimar tayini meselesinin çözülmesi uzun sürmüştür. Dersaadet, mahalli halkın maddi yardımlarıyla inşâ olunan Emevi Camii'nin gene mahalli bir mimar tarafindan yapılmasını benimseyip Şam'dan teklifler istemiş, fakat Emevi Camii'nin hem hacim hem de tarihi ehemmiyeti göz önüne alındığında mahalli mimar, mühendis ve kalfaların bu ağır yükün altından kalkamayacakları gerçeği ile karşı karşıya kalınmıştır. Aylar süren yazışmalarda bu problem açıkça izlenmektedir. Suriye'de bulunan heyet tarafından Dersaadet'e yapılan tekliflerde Beyrut Vilayeti Başmühendisi Beşare Efendi'nin Lozan'da mimarlık eğitimi alıp mezun olmuş olan ve modern mimari teknik uygulamalarını iyi bilen oğlu Armon Beşare öne çıkmıştır. Fakat Armon Beşare'nin yeni mezun olup iş tecrübesinin olmaması, inşa edilecek camiinin büyüklüğü ve tarihi önemi haiz olması ile camii inşaatının mahalli halkın ianesi ile yapılacak olması sebebiyle bu teklif kabul görmemiştir (BOA, BEO.652/48851; 662/49604-1-2) .

Ticaret ve Nafia Nezaretinden teklif edilen bir diğer kalfa 4000 kuruş maaşla Çolikofer Efendi'dir. Fakat Dersaadet'in üzerinde hassasiyetle durduğu konu inşaatın mahalli halkın ianesiyle yapılacak olmasından ötürü merkezden bir mimar veya kalfanın Suriye vilayetine gönderilmesinin uygun olmamasıdır. Bir müddet mimar gönderilmesinden vaz geçmenin uygun olacağına karar verilir. Teklif edilen mimarlar arasında sermimar Agop Çırakçıyan da vardır ve eğer bir mimar gönderilecekse bunun Agop Çırakçıyan olması evladır, diye düşünülür. Bu tartışma aylarca Şam ile İstanbul arasında yazışmalara sebep olur. Bu tartışmanın belgelere yansıyan halini şu şekilde görebiliriz: “... arz ve beyan olduğu veçhile mezkur camiinin yanan yerlerinin Halife sayesinde yeniden imart ve ihyası için ihtiyar olunacak masraf yaklaşık 60000 lira ve şekl-i suret-i inşaat dahi dekayık-ı fenn-i mimariye müteallik olmak hasebiyle mezkur ameliyat ve inşaatın kavâid-i mahsusa-i fenniye tevfik ve tatbiki emr-i mühimmenin husulüne kanâat-ı kamile mutlaka berid-i iktidara tevdi'-i maslahata kabil olabileceği derkar ise de vilayet-i müşarun ileyhanın suret-i işaratına göre iane akçesinden tesviye maaşıyla mimar tayini canib-i ahâliyeden tesviyesi taahhüd olunan mebaliğin emr-i istishalinde husul-i müşkilatı müstelzem olacağı anlaşılmasına ve nezaret-i müşarun ileyhaca müntehab olunan 2 mimardan Mösyö Çoklikofur'un maharet ve rusuhu daire-i askeriyece malum değilse de Agop Çirakyan Efendi müddet-i medide daire-i inşaat resimhanesinde resimcilikle istihdam olunarak hususat-ı tersimiyede haiz-i maharet olmagla beraber bu gibi mühim dakaylk-i fenniye kemal-i vukuf ve itlağı müstelzem olan ameliyat-ı inşaiye mimarlı̆̆ına tayini vilayetçe Armon Beşare Efendi hakkinda dermeyan olan mahzura ma'a-ziyade sebeb-i zuhur olmuş olacağına binaen vilayetçe daha önce taleb ve dermeyan olduğu veçhile mahalli evkaf varidatından tesviye-i maaş ile muktedir bir mimar tayin ve i'zamı kabil olmadığı halde iane akçesinin istihsalinde dermeyan olunan ihtimal-i müskilatın tahakkuk ve hudusuna mahal kalmamak üzere vilayet-i müşârun ileyhânın terviç-i iş̧ar-ı ahiri münasip olur gibi mütalaa olunmuş ve irsal buyurulan 
tezkere ve tahrirat leffen iade ve takdim kılınmış olmagla ifa-yı muktezast ... rey ve irade-i aliyye-i sadaret-penahileridir. Ol babda..." (BOA, BEO. 688/51586-1; ŞD. 2284/28-2 16 Ekim 1895) diye devam eder. Ayrıca bir başka belgede de camii inşaatına emek vermiş olan sanatkarân-1 İslam'dan -vasfı belli olmamakla beraber- mimar Abdulganî Hamavî Efendi'nin de adı geçmektedir (BOA, İ.ML.59/71).

1895 senesinin sonunda mahalli halktan toplanan yardım paraları bitmiş; 12000 liraya daha ihtiyaç olduğu Dersaadet'e bildirilmiş, Hazret-i Pâdişâhi'den yardım talebinde bulunulmuştur (BOA, İ.HUS.44/111). Devletin içinde bulunduğu zor şartlar altında üç yılın sonuna gelindiğinde sadece camiinin çevresinde bulunan dört adet meşhedin inşâsı tamamlanmış olmakla beraber diğer yandan da inşaat faaliyetleri devam etmekte olup ayrıca Şam eşrafindan mühim şahsiyetler tarafindan inşaat için komisyon kurulmuştur (BOA, Y.A.HUS.361/116-01). 1897 senesi sonbaharında Camî için toplanan paralar inşaatın büyüklüğü, yapılacak tamiratın fazlalığı sebebiyle kifayet etmez ve Evkaf Nazırı Seyyid Gâlibullah tarafından camii vakfının yıllık vâridat fazlası olan 40000 kuruşun inşaatın tamamlanması için kullanılmasına karar verilir (BOA, ŞD.142/57).

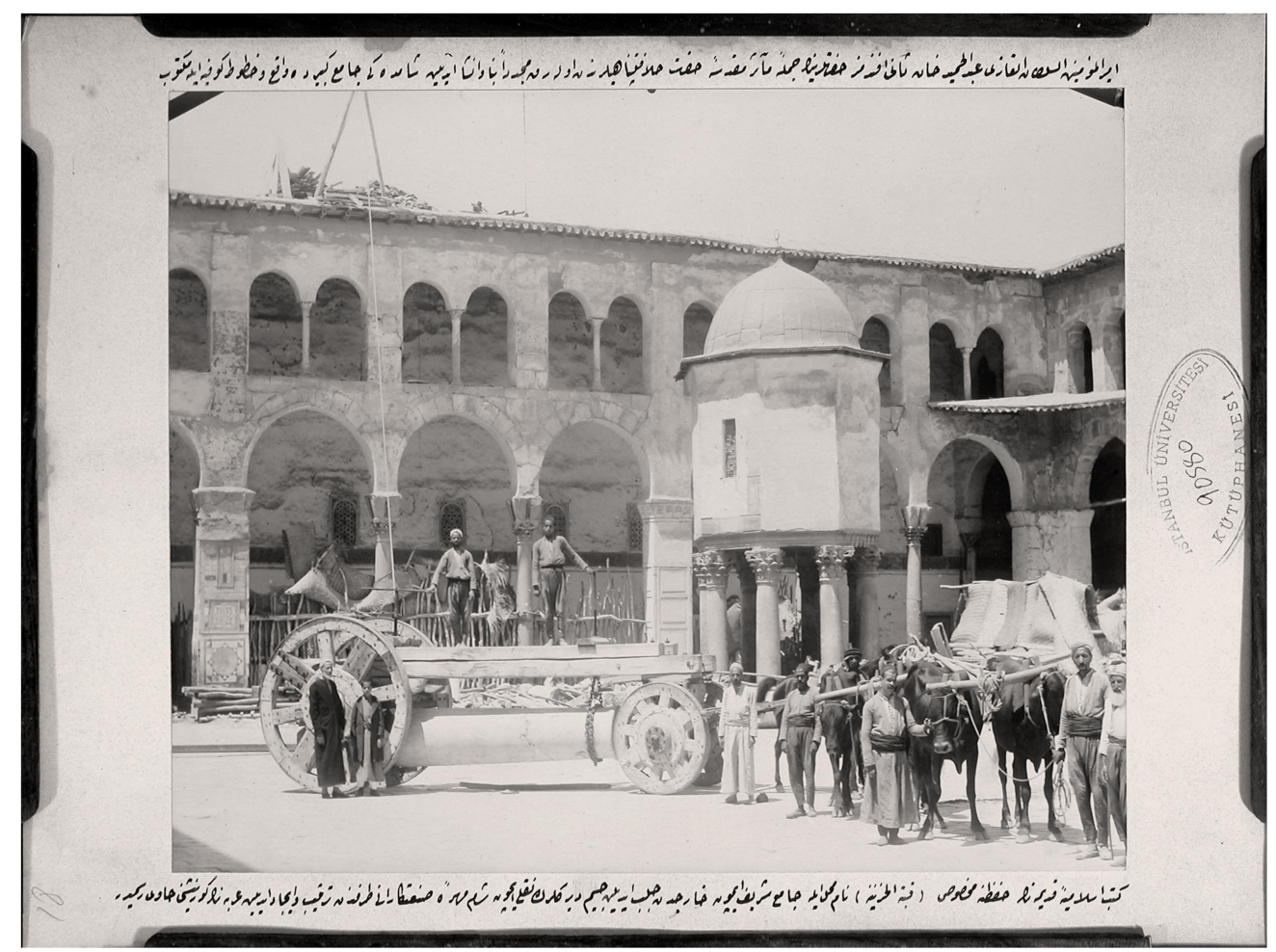

Fig. 2. Camii Sütunlarının Binaya nasıl Taşındığını Gösteren Fotoğraf (İÜ, Nadir Eserler Ktp)

Aynı günlerde câmîin iç süslemeleri de yavaş yavaş yapılmaya başlanmıştır. Suriye Valisi Tahsin b. Hüseyin Nazım'ın gönderdiği telgraftan anlaşıldığına göre Hanefî ve Şâfî mihraplarında yanmadan önce bulunan kûfî yazılı ayetler eski resimleri ile karşılaştırılarak fotoğraf ve çizimde erbab-1 ihtisasdan olan topçu kolağası Mehmed Nuri Efendi tarafından yeniden tertip ve aslına mutabık olarak yazılmış ve aynıyla taşlar üzerine hakkedilmiştir. Bu yazıların fotoğrafları Kolağası Mehmed Nuri Efendi ile beraber Dersaadet'e gönderilmiş, ayrıca kendisine mükâfaât verilmesi de talep edilmiştir. Bu durumu anlatan belge şöyledir: "Mabeyn- $i$ Hümayun Cenab-i Mülukane Başkitabet-i Celilesine, Atufetli Efendim Hazretleri, Şam'da yanmiş olan Halifenin ehemmiyet-i tarihiyyesiyle mütenasip bir surette derdest tamir bulunan cami-i şehir Emeviye'nin Hanefi ve şafi mihrablarında Kufi hattlyla kadimen mevcud iken harik 
münasebetiyle zedelenmiş ve mekteb-i fünun-i harbiye-yi şahane fotoğrafhanesine memur olup mezunen şamda bulunan fotoğraf ve zinfoğrafa (?) müteallik fünun-ı umumiyede erbab-ı ihtisasdan olan topçu kolağası fütüvvetli Mehmed Nuri? Efendi tarafindan bu kere cem've tertip ve aslına mutablk olarak yeniden tahrir ve ayniyla taşlar üzerine dahi tersim edilmiş olan âyât-l kerimenin fotoğraf vasitasıyla istinsah edilen iki kut'a resmi manzur-i âli buyurulmak üzere bu kere Dersaadet'e avdet eden Efendi-i müma ileyhe teslim edilmis ve müma ileyhin mücerred gayret ve hamiyyet-i diniyyesi saikası olarak cami-i şerif-i mezkuru ziynetdar eden işbu hizmet-i fahirası cidden şayan-l takdir ve taltif bulunmus olmagla bu yolda aylarca sarf ettiği himem-i meşkuresine mükafaat tensib buyurulacak suretle istikmal-i esbab-ı mesruriyetine müsaade ve delalet-i celile-i dâderâneleri suret-i mahsusada rica olunur. Ol babda emr-i ferman men-lehû'l-emrindir. Suriye Valisi Tahsin b. Hüseyin Nazım"(BOA, Y.MTV.167/73).

Camiinin tamir ve yenilenmesi on yıl kadar sürmüş ve şu tamirat yapılmıştır: Sütunlar başlıkları ile beraber mezze taşından yananların aynıları taklit edilerek imal edilmiş; kemerler yerli taştan ara boşlukları Marsilya tuğlasından, yüksek olan çatı demir konstrüksiyon üzerine ahşap olarak, İtalya mermerinden dört mihraplı dört metre yüksekliğinde bazı yerleri renkli taş ve mozayiklerle kıble duvarı inşa edilmiş, hem ana kapılar, hem pencere çerçeve ve pervazları katranlı çam ve ceviz ağacindan geometrik desenler ve oymalarla, minber Marmara mermerinden tezyinatlı olarak, kubbeyi tutan dört büyük sütun da muhkem ve duvarların yüzleri çeşitli geometrik mozayik süslemelerle inşa edilerek hizmete açılmıştır. Umumiyetle her işin sonunda o işte emeği geçenlere mükafâat verildiği gibi Emevî Câmii'nde de emeği geçenler ödüllendirilmişlerdir. Suriye valisi Hacı Hüseyin Paşa da kendisine nişan verilen bu kişiler arasında yer almıştır.

Sonuç olarak üzerinde sanat tarihi alanında ülkemizde neredeyse hiç yayın bulunmayan Şam Emevi Camii hakkında bu kapsamda bir ilk olan çalışma tamamen Osmanlı Arşivi'nde bulunan belgelerle inşa edilmiş olması bakımından tamamen orijinal bir makaledir. Hakezâ yangın hadisesini belgeleyen fotoğraflar da Sultan II. Abdulhamid'in İstanbul Üniversitesi, Nadir Eserler Kütüphanesi'ndeki fotoğraf albümlerinden temin edildiği için ayrıca bir öneme haizdir. Camiinin yangının hemen akabinde yenilenmesi Osmanlı Devleti'nin siyasal, sosyal ve ekonomik olarak en zor yıllarında vukû' bulmuştur. Sultan II. Abdulhamid'in Şam Emevi Camii restorasyonu aynı yüz yıl içinde babası Abdülmecid'in Mescid-i Nebevi büyük restorasyonundan sonra devletin merkez dışındaki topraklarda yaptığı bir başka büyük yenileme inşaatıdır. Sultan Abdulmecid devletin hazinesinden ve ilaveten kendi şahsi gelirinden Mescid-i Nebeviyi tamir ve tecdid ettirmiş; Sultan Abdulhamid ise Dersaadet kontrolünde mümkün mertebe mahalli halkın ve diğer hayır sahiplerinin bağış ve yardımlarıyla camiiyi yeniden inşa ettirmiştir. Her iki restorasyon da devletin siyasi ve mali açıdan en zor devirlerine denk gelmiş buna rağmen her ikisi de başarıyla sonuçlanmıştır. Restorasyon sürecinde dikkat çeken husus, yenileme çalışmasında inşaatının yapılış şekli üzerinde hassasiyetle durulması ve her hangi bir ihmal veya sıradanlığın söz konusu olmayışıdır. Tamiratın her kademesinde mahalli halka, mahalli ustalara, mahalli malzemeye ve mahalli mimariye önem verilmesi, kullanılması ve vurgu yapılması hem o dönem şartları için hem de Sultan II. Abdülhamid'in sürdüğü politikalar açısından en önemli noktalardan biridir. Belgelerden anlaşılan o devirde yeni moda olmaya başlamış olan betonarme inşaata sıcak bakılmamasıdır. Restorasyon sırasında "tarz-1 kadim" yani orijinal haline uygun, fakat tehlikelere karşı tedbirli olarak veya belli yerlerde yeni mimari malzeme ve teknolojiyi kullanarak inşaat yapılmasına öncelik verilmiştir. Restorasyonun başarılı olmasında kurumlar aras1 koordinasyonun ve devletin en yüksek kademesinin uyumu en mühim noktayı teşkil etmektedir. Üzerinde durulması gereken bir başka husus ise inşaatı yapacak ve kontrol edecek mimar tayinidir. Devletin konuya yaklaşımı mahalli maddi katkılarla yapılacak inşaata mahalli 
yetkin bir mimarın nezaret etmesi doğrultusunda olmuştur. Ancak mahalli mimar ve kalfaların yetenekleri câmînin hâiz olduğu büyüklüğü ve kudsiyeti kaldıracak kuvvet ve kudrette olamadığından Dersaadet'teki Sermimar Agop Çırakçıyan'ın görevlendirilmesi bir mecburiyet halini almıştır. Sultan, Şam'dan gelen bilgileri merkezde konunun uzmanlarının görüşleri doğrultusunda değerlendirmiş, hatta Âsâr-1 Atîka Müzesi Müdürü Halil Edhem Bey'i yerinde inceleme yapması için gönderme kararı almıştır. Devletin içinde bulunduğu çeşitli karışıklıklar sebebiyle camiinin tamiratı yaklaşık 10 yıl kadar sürmüştür. Önemli olan bir diğer husus ki bu Sultan Abdulhamid'in mühim bir özelliğidir, hem yangın öncesi hem yangın sonrası camiinin bütün bölüm ve unsurlarının fotoğrafları çekilerek belgelenmiş olmasıdır. $\mathrm{Bu}$ fotoğraflar camiinin yeniden eski haline getirilmesinde en önemli rolü oynayan amillerden olduğu gibi günümüzde de o devirde vukû bulan yangının büyüklügünü, binaya ve çevreye verdiği zararı göstermesidir, denilebilir.

\section{KAYNAKÇA}

Ateş İ. (1978). “Şam Ümeyye Câmi ve Vakfiyesi”. Vakıflar Dergisi XII (1978) 20-78.

Dündar A. (2001). "Osmanlılarda Tamir Süreci, Çeşitleri ve Bazı Selçuklu Yapılarındaki Uygulamalar". Haz. O. Eravşar, I. Uluslararası Selçuklu Kültür ve Medeniyeti Kongresi Bildiriler (2001) 269-281.

Ertaş M. Y. (2001). “1759 Şam Depremi’nde Büyük Hasar Gören Emeviye, Selimiye ve Süleymaniye Câmilerinin Onarımı”. Haz. Ş. Ercebeci \& A. Şimşek-Canpolat, Ortadoğu'da Osmanlı Dönemi Kültür İzleri Uluslararası Bilgi Şöleni Bildirileri (25-27 Ekim 2000). Cilt I 2(001) 241-251.

Yazicı T. (n.d.). "Emevi Camii". DIA XI (n.d.) 108-109.

Başbakanlık Osmanlı Arşivi (BOA): BEO 348/26041-1-3; BEO, 489/36629; BEO. 591/44256; BEO. 652/48851; BEO. 662/49604-1,2; BEO. 688/51586-1; DH.MKT. 150/25; DH.MKT. 204/86; H.MKT. 300/75; HR.SYS. 26/69; İ.EV. 9/28-001-001, 002-007; İ. EV. 9/28-004; İ.HUS. 17/13; İ.HUS. 17/111; İ.HUS. 30/100; İ.ML. 59/71; MF. MKT. 517/27; ŞD.142/57; ŞD. 2284/28-2; Y.A.HUS.361/116-01; Y.A.HUS.361/116-02; Y.A.HUS. 291/13; Y.MTV. 167/73; Y.PRK.AZJ. 27/79-1; Y.PRK.AZJ. 27/7912; Y.PRK.BŞK.52/59; Y.PRK.DH.7/35; Y.PRK.EV.2/22-1,2; Y.PRK.UM. 29/14; Y.PRK.UM. 29/14. 